in passages such as these that Husserl displays an instructive sympathy for psychology, including the integrative principle of the Gestalt concept, and problem pictures with their differing degrees of mental awareness.

This is not an easy book to read. The style is difficult in itself, and encumbered with a veritable plethora of exclamation marks. In addition, the author has the tiresome habit of writing 'if' when he means 'whether'.

All in all, this is a welcome new member of the Phaenomenologica series, and exhibits Husserl as a precursor of much that is fundamental in modern logic.

F. I. G. Rawlins

\section{CHURCH AND STATE}

\section{Transactions of the American Philosophical Society}

New Series-Vol. 54, Part I: Rome and the City of God: an Essay on the Constitutional Relationships of Empire and Church in the Fourth Century. By Prof. Karl Frederick Morrison. Pp. 1-56. (Philadelphia: The American Philosophical Society, 1964.) 1.50 dollars.

CHRISTIANITY started as a Jewish sect in Palestine. 4 For its members, the Jewish law was obligatory and the outlook on the world in general and the Messiahship of the Founder was Eastern, Syriac and not Greek. Greek thought started with the cosmos and sought to understand human life (and God in relation to life) from the cosmos; Syriac thought started from the idea of the Living God and sought to understand human life in the cosmos from its vision of God.

Palestinian Christianity was largely destroyed during the wars waged by 'Titus, but previously had taken root in a number of gentile settlements. Not a few missionaries, including Saint Paul, helped in this dispersion of its beliefs. Maybe, too, some gentiles who had been influenced by the new thought, and had been driven out of Jerusalem at the time of the riots which led to the death of Stephen, also played their part in the spread abroad of the new religion. But the gentiles were Greek in thought and certainly were not interested in Jewish laws. After a hard fight, Saint Paul persuaded the Jerusalem Christians to relax most of these laws and practices including, especially, circumcision. However, the problem of making intelligible the essentially Syriac ideas to the Greek mind remained, as well as the organizing of the several little groups of believers into a Church. The latter problem was solved early, indecd before A.D.180, as the Roman Empire could be used as a model by such organizers as Ignatius and others. The Church they built up was flexible enough to allow for expansion and indeed lasted until the time of the Reformation.

The problem of translating Syriac thought into Greek terms was another matter and involved much controversy. Heresies also arose (especially the Arian in the fourth century), and these complicated the problem. The main question was: What was the nature of the Founder and how could it be expressed in words? It was not until the fifth century that a solution to the problem satisfactory to the majority was attained at the Council of Chalcedon.

When Constantine the Great was converted to Christian. ity and the Roman Empire became nominally Christian in the middle of the fourth century, still another vital problem arose: What should be the relationship between the State and the Church, which, by definition, already had the Founder as the divine Head? On one hand, the State did not want an Imperium in imperio; on the other, the Church obviously should not be controlled by the secular arm. The idea of the 'City of God' emerged and, with safeguards, a duality grew up which lasted throughout medieval times-the spiritual arm, the Pope; and the secular arm, the Emperor. In this connexion the influence and ideas of Saint Athanasius, of Saint Hilary and, a little later, of Saint Ambrose were vital, and Prof. Morrison, in Rome and the City of God, considers them in some detail. If the new Church had fallen completely into the hands of the State, humanly speaking it would have died with the Roman Empire, especially in the West. As it was, the opposite occurred and the early Popes inherited much of the power and influence which had previously been wielded by Rome.

Of course, the problem was not settled for all time in the fourth century; the relationship in France between the Church and the State is still uneasy, and the British solution, where the State appoints the chief church officials but then allows them liberty of action, does not appeal to everyone. Prof. Morrison starts with an introduction and then deals in detail first with the legal principles and later with the theological problems involved. The result is a learned work of great interest, but the general reader should have some knowledge of the subject as a whole before tackling it.

\section{C. BurkitT}

\section{HEAT TRANSFER}

\section{Chemical Engineering Practice}

Vol. 7: Heat Transfer. General Editor: Herbert W. Cremer. Pp. vi $+460+$ xiii. (London: Butterworth and Co. (Publishers), Ltd., 1963.) $100 s$.

\section{J OLUME 7 in the series Chemical Engineering Practice} covers the ground of heat transfer, a field of major importance in chemical engineering. Four chapters, which form the greater part of the text, are devoted to heat transfer and are followed by two chapters on drying and a final chapter on heating and ventilation.

The first chapter, by Dr. Franklin and Mr. Hartland, on conduction, forms an extremely good introduction to the basic mechanism of heat transfer and provides a general introduction to the text. The authors have succeoded in discussing both steady- and unsteady-state conditions and two-dimensional flow, but there is a somewhat hurried look about parts of the explanations, and the inclusion of a number of worked examples illustrating the techniques would have been valuable to the practising engineer.

The next three chapters, on transfer by convection, by boiling and by radiation, which have been written by Prof. Roberts and Mr. Cass from the Houldsworth School at Leeds, form the most extensive section of the book. The chapter on convection is well presented and the importance of this mode of transfer is well brought out, but there are sections, such as heat flow in annuli, where a more detailed account of the problems would have been appreciated by the reader. The authors have been reluctant to be in any way definite in recommending particular expressions for the calculation of the heat transfer coefficients under varying conditions, and more on the oxpec. ted accuracy of such correlations would have helped. The use of packed beds for reactors and the ever widening application of the fluidized bed technique are oxamined, but more information on the performance of large units would have helped the designer, who is at present uneasy about the application of data from small units. There is much research in this field, but the precise mechanism of heat transfor and the problems of geometry have not yet beon cleared for accurate design.

Chapter 3, on heat transfer with phase chango, deals extensively with evaporation and boiling, but some of the more recent correlations on nucleate and two-phase transfer should have been included. The designers hero are perhaps more concerned with heat flux, and the problems of reproducibility and steady values, than with trying to obtain exceptionally high values of transfer coefficients. Some of the practical features of the desirable extent of vaporization, either per pass in a tube or per cycle in a reboiler, have been treated rather 